DIW BERLIN

Discussion

Papers
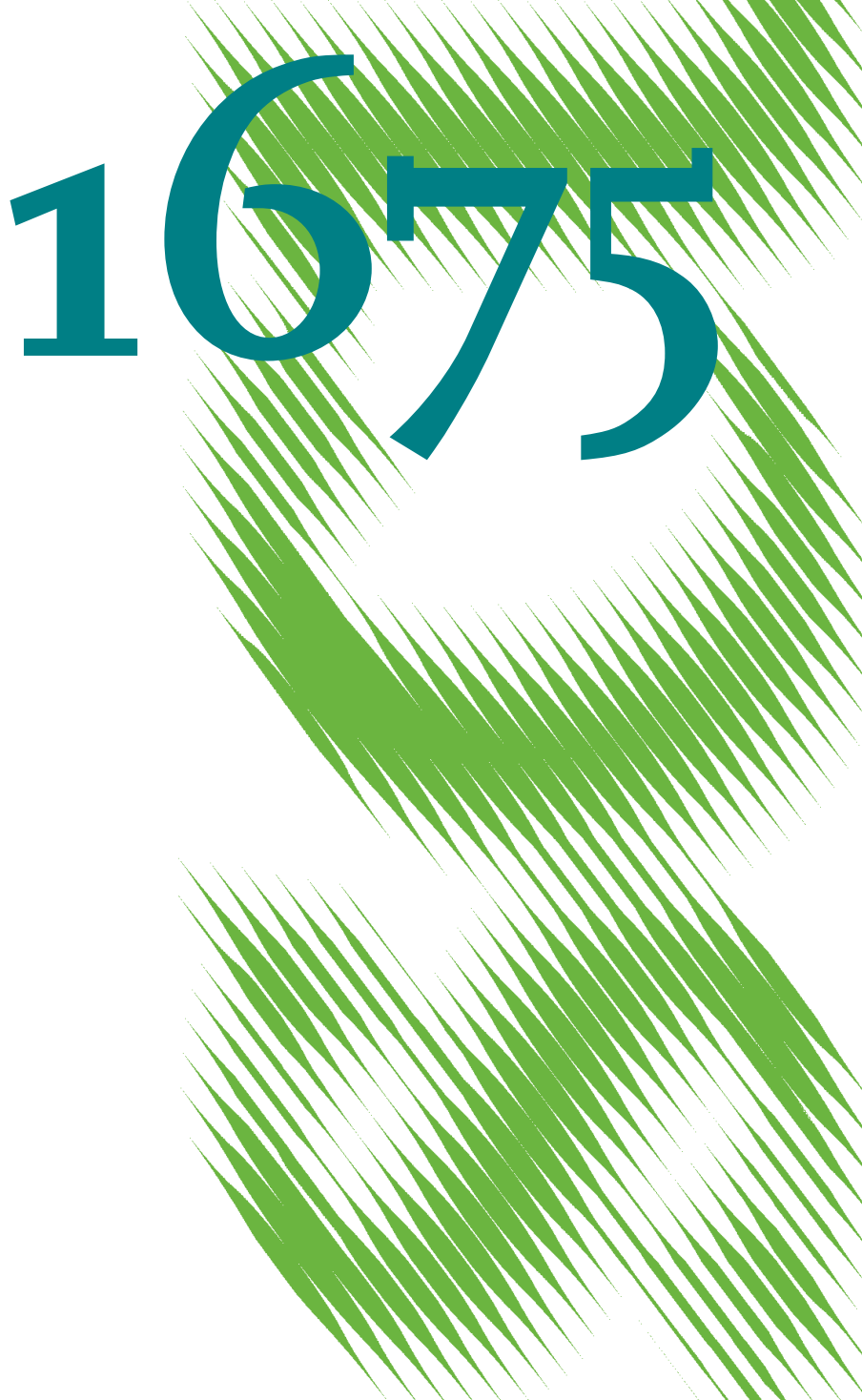

Towards an East German

Wage Curve - NUTS Boundaries,

Labour Market Regions and

Unemployment Spillovers 
Opinions expressed in this paper are those of the author(s) and do not necessarily reflect views of the institute.

IMPRESSUM

(C) DIW Berlin, 2017

DIW Berlin

German Institute for Economic Research

Mohrenstr. 58

10117 Berlin

Tel. +49 (30) $89789-0$

Fax +49 (30) $89789-200$

http://www.diw.de

ISSN electronic edition 1619-4535

Papers can be downloaded free of charge from the DIW Berlin website:

http://www.diw.de/discussionpapers

Discussion Papers of DIW Berlin are indexed in RePEc and SSRN:

http://ideas.repec.org/s/diw/diwwpp.html

http://www.ssrn.com/link/DIW-Berlin-German-Inst-Econ-Res.html 


\title{
Towards an East German wage curve - NUTS boundaries, labour market regions and unemployment spillovers
}

\author{
Reinhold Kosfeld ${ }^{1}$ and Christian Dreger $^{2}$
}

\begin{abstract}
The relevance of spatial effects in the wage curve can be rationalized by the model of monopsonistic competition in regional labour markets. However, distortions in extracting the regional unemployment effects arise in standard regional (i.e. NUTS) classifications as they fail to adequately capture spatial processes. In addition, the nonstationarity of wages and unemployment is often ignored. Both issues are particularly important in high unemployment regimes like East Germany where a wage curve is difficult to establish. In this paper, labour market regions defined by economic criteria are used to examine the existence of an East German wage curve. Due to the nonstationarity of spatial data, a global panel cointegration approach is adopted. By specifying a spatial error correction model (SpECM), equilibrium adjustments are investigated in time and space. The analysis gives evidence on a locally but not a spatially cointegrated wage curve for East Germany.
\end{abstract}

Key Words: Wage curve, labour market regions, global cointegration, spatial error-correction model

JEL classification: J30, J60, C33, R15

\footnotetext{
${ }^{1}$ University of Kassel, Institute of Economics

${ }^{2}$ German Institute of Economic Research (DIW Berlin) and European University Viadrina Frankfurt (Oder)
} 


\section{Introduction}

Since the discovery of the wage curve by Blanchflower and Oswald (1990, 1994, 1995) in the early 1990s, a large strand of the literature has been devoted to this topic. Blanchflower and Oswald (1995) present evidence for a negative relationship between wages and the regional unemployment rate. Such a curve can be rationalized by profit maximization in non-competitive markets. One explanation of why a worker living in a high unemployment area earns less than a jobholder with the same individual characteristics in an area of low unemployment is given by the efficiency wage model (cf. Blanchflower and Oswald 1994; Card 1995). Employers have the opportunity to lower the efficiency premium when outside options of workers are reduced in deteriorating labour markets.

Blanchflower and Oswald (1994) detected a stable elasticity of wages with respect to unemployment of around -0.10 for a number of countries and periods. However, this "empirical law of economics" (Card 1995) could not be confirmed by follow-up studies. Although the difference to the bias-corrected estimate of -0.07 of Nijkamp and Poot (2003) is small, their meta-study shows considerable heterogeneity among estimated wage curve elasticities. Even after excluding outliers, elasticities vary between -0.50 and +0.10 . Non-unique results are also striking in the German case. Controlling for regional fixed effects Wagner (1994) does not find a significant relationship between wages and unemployment for West Germany in the second half of the 1980s. Similarly, Pannenberg and Schwarze (1998) fail to detect a standard wage curve for East Germany in the early 1990s. In contrast, after controlling for endogeneity of the unemployment rate, the study of Baltagi, Blien and Wolf (2000) is favourable to the existence of an East German wage curve in the 1990s.

Pannenberg and Schwarze (2000) investigate the wage curve for West Germany at the regional level for a period of five years before and after the German unification. From an error correction framework, a dynamic autoregressive wage curve equation is derived with region- and time-specific fixed effects. While there is evidence for an inverse relationship between wages and unemployment in the long-run, substantial inertia occurs in the short-run. Nonetheless, the outcome supports the existence of a long-run relationship between wages and unemployment with partial adjustment towards the long run equilibrium. The cointegration approach of Ammermüller et al. (2010) confirms a weakly significant negative long-run effect of regional 
unemployment on wages with partial adjustment. These results are in line with the analysis of Baltagi, Blien and Wolf (2009) who revealed a wage curve for West Germany with substantial autoregressive behaviour.

Previous studies are often plagued by serious deficts. For instance, inconsistent parameter estimates may arise from ignoring the endogeneity of the unemployment rate. Moreover, labour market conditions in surrounding regions are often excluded and may constitute an omitted variable bias (cf. Greene 2011, p. 386). Longhi, Nijkamp and Poot (2004) refer to the theory of monopsonistic competition to justify the presence of unemployment spillovers in the wage function. If commuting costs to workplaces outside the home region are relatively low, working conditions in neighbouring regions will likely affect the bargaining power of workers and employers. In contrast to Büttner (1999), Longhi, Nijkamp and Poot (2004) do not find an inverse effect of unemployment in neighbouring regions on local wages for West Germany. Büttner (1999) discovers even a higher unemployment elasticity in absolute value if larger labour markets are considered. This finding is corroborated by the recent studies of Fingleton and Palombi (2013) and Kosfeld and Dreger (2017) at the district level. Baltagi, Blien and Wolf (2012) argue that myopic behaviour of agents in labour markets is a possible explanation for the lack of unemployment spillovers. In their spatial approach to the East German wage curve, Elhorst, Blien and Wolf (2007) discuss a test structure for estimating the wage curve elasticity without unemployment spillovers. In contrast to Western Germany, evidence on the role of spatial effects in wage determination and labour market adjustment is scarce for East Germany. Regional labour markets are still very distinct in both areas, with respect to labour supply, labour productivity, wages, unemployment, bargaining coverage and union density (Schnabel 2016).

This paper investigates the relationship between wages and unemployment for East German regions over the period of 1995 to 2010. The East-West divide in the levels of wages and unemployment is a cogent cause for not mixing data sets of both parts of the economy. Responses of wages to changes in unemployment are expected to differ under diverse labour market conditions. In slack labour markets very limited wage cuts may not necessarily cause workers to quit their jobs. Large scale active labour market programs were launched in East Germany to support the economic transformation and to tackle the social consequences of higher unemployment 
(Hagen 2003). For these reasons, the existence of an East German wage curve defines a distinct topic of research (cf. Pannenberg and Schwarze 1998; Baltagi, Blien and Wolf 2000; Elhorst, Blien and Wolf 2007).

We extend the stock of knowledge in this area in several respects. First, the influence of labour market conditions in neighbourhood regions on local wages is examined. Up to now, no results on the role of spatial unemployment spillovers is available for East Germany. Second, wage dynamics are investigated on the basis of a spatial error correction model where adjustment to equilibrium is examined with respect to time and space. This leads to the concepts of global and local cointegration essential for the analysis. Third, we show that the impact of direct and spatial effects may be seriously biased if the regional units are defined by administrative boundaries. Therefore, wage curve elasticies should be estimated in the framework of labour markets delimited by functional criteria.

The paper is structured as follows. Section 2 reviews the literature on the wage curve with a special focus on the German evidence. Section 3 outlines the concept of the wage curve extended by spatial effects. The econometric metholology is discussed in section 4, and the empirical findings are presented in Section 5. Section 6 provides a sensivity analysis of the results, and Section 7 concludes with some policy recommendations.

\section{Previous studies on the wage curve}

The negative relationship between wages and regional unemployment detected by Blanchflower and Oswald $(1994,1994)$ claimed a stable unemployment elasticity of wages of approximately -0.1 , independent of the time period and the countries in the analysis. Since the mid of the 1990s this "empirical law" triggered numerous empirical studies. A lot of research was done for the German economy. The strand of panel studies on the German wage curve was launched by the work of Wagner (1994) and Baltagi and Blien (1998) who provided evidence for the relationship in pre-unification periods.

After 1990 the analysis of the wage curve is still conducted separately for the Western and Eastern part of Germany due to substantial differences in economic conditions. Virtually all studies make use of the same regional and temporal disaggregation. Annual data for different time periods are analysed for urban and 
rural districts according to the NUTS-3 classification of the European Union. ${ }^{3}$ The studies differ essentially in the way they cope with multilevel data, the endogeneity problem, spatial and dynamic effects. The nonstationarity of variables is usually ignored. For the West German case, wage curves for different groups of workers have been estimated too.

Pannenberg and Schwarze (1998) estimate the wage curve for Eastern Germany with data drawn from the German Socio Economic Panel over the 1992-94 period. After linking individual data to the 35 labour office districts a negative employment elasticity is found in a pooled OLS model with fixed regional effects. However, feasible GLS estimation of a panel model with random individual and regional fixed effects does not confirm the finding, as the negative relationship is no longer significant. After replacing the unemployment rate by the regional job search rate the authors find a wage curve elasticity of -0.14 which is significant at the $5 \%$ level. The broader measure of labour market slack is used to account for large scale active labour market programs. The elasticity declines to -0.53 , if simultaneity bias is taken into account.

As the study of Pannenberg and Schwarze (1998) is restricted to a short period at the start of transition of a centrally planned economy to a market economy, one can scarcely interpret their finding in favour a long-run relationship between wages and regional unemployment. Excluding the first two transition years from their sample, Baltagi, Blien and Wolf (2000) examine the existence of an East German wage curve over the 1993-98 period. Using regional unemployment rates of the 114 administrative districts, the effective sample size is increased considerably. On the basis of the two-ways fixed effects estimator the wage curve is not supported. The picture changes when the unemployment rate is instrumented by exogenous regressors and their lagged values. After controlling for endogeneity of the unemployment rate in this way, first-difference 2SLS estimation yields a highly significant overall unemployment elasticity of -0.15 .

Regions usually refer to administrative boundaries. Büttner (1999) argues that the neighbouring regions may be related through common shocks and activities of

\footnotetext{
${ }^{3}$ Exeptions are the studies of Pannenberg and Schwarze (1998, 2000) and Ammermüler et al. (2010). While the former authors make use of employment office districts ('Arbeitsamtsbezirke') and spatial planning regions ('Raumordnungsregionen') within the territory of the states (the German 'Länder') as spatial units, the latter work relies on state level data.
} 
agents operating in larger labour markets. In his investigation of West German wages in manufacturing industry over the 1987-94 period he shows a downward bias of the estimated unemployment elasticity of wages if spatial effects are neglected. Using the inverse unemployment rate as a regressor in a restricted fixed-effects spatial Durbin model, it is found that regional wages respond to variations in the regional unemployment rate with decreasing extent. For the 327 West German districts, the estimated elasticities are in the range of -0.040 to -0.005 in the non-spatial case and -0.053 to -0.008 in the spatial case.

Longhi, Nijkamp and Poot (2006) introduce spatial effects into the wage curve by drawing on monopsonistic competition. If employment opportunities in nearby regions are available to workers, the threat of unemployment will decrease. Employees are aware of economic conditions in surrounding areas. However, as workers face commuting and migration costs, employers will have some degree of monopsonistic power. In their study of the West German wage curve over the 1990-97 period, Longhi, Nijkamp and Poot (2006) show the importance of spatial effects for the 327 NUTS-3 regions. Due to the interaction of the unemployment rate with an index of accessibility and agglomeration, the estimated wage elasticity varies with the unemployment level. However, 2SLS fixed-effect estimation of a simplified model without quadratic terms gives evidence for a negative elasticity around -0.02 . Interpretation problems occur as the sign of the spatially lagged unemployment rate is positive, in contrast to expectations.

In estimating the East German wage curve for period 1993-99 period, Elhorst, Blien, and Wolf (2007) focus on the treatment of potential endogeneity in spatial panel models with time-specific effects. Their testing strategy is as well applicable to region-specific effects. For a panel of 114 East German districts, different estimators of the unemployment elasticity are compared. After establishing regional unemployment rates not to be strictly exogenous, 2SLS with temporal and spatial differences in the presence of fixed effects is preferred. The estimator corroborates the wage curve hypothesis for East German with an elasticity value of -0.039 that is significant at the $5 \%$ level.

Dynamic effects in the wage curve are often neglected. For West Germany, Pannenberg and Schwarze (2000) provide in their analysis of 74 regions over the period 1985-94 evidence on inertia of regional wages in the short-run. For the 
Arellano-Bond estimator, a highly significant value for the autoregressive parameters of 0.30 results. In the long-run, a negative equilibrium relationship between wages and unemployment is established. The estimated wage elasticity with respect to unemployment of -0.04 is low in absolute value but significant. Spatial effects have not been included.

Ammermüller et al. (2010) adopt a cointegration approach in investigating the wageunemployment nexus for Italy and Germany. For Germany, panel analysis is based on microcensus data on net income and individual characteristics in combination with state level unemployment rates. Spatial spillovers are ignored, as the administrative regions are quite large. Fixed effect estimation fails to confirm the wage curve hypothesis for West Germany for 1996-2003. In contrast, a significant negative relationship between wages and regional unemployment is established for East Germany employees, females and low educated workers.

Baltagi, Blien and Wolf (2012) investigate the wage curve relationship for West Germany over the period 1980-2004 with individual wage data covering all 326 NUTS-3 regions. Lagged wages are embedded to control for dynamic effects. The presence of regional unemployment spillovers is tested using different spatial weights matrices. After instrumenting the unemployment rate and its spatial lag by their time lags, a highly significant and robust long-run wage curve elasticity of about -0.04 is inferred for West Germany. In virtually all cases, spatial effects arising from unemployment are not detected. The signficance of the autoregressive parameter corroborates the dynamic specification of the wage curve.

The recent study of Kosfeld and Dreger (2017) on the relationship between wages and unemployment focuses on West Germany. The work integrates spatial effects in a panel cointegration framework. Using panel data for 325 NUTS-3 regions over the period 1995-2005, a stable long-run wage curve with spatial effects is found. The unemployment spillover effect turns out to be even stronger than the local impact of unemployment on wages. However, the instrumental variable (IV) estimator of the unemployment elasticity is below one-tenth of the value suggested by Blanchflower and Oswalds's $(1995,2005)$ empirical law. 


\section{The concept of the wage curve}

The wage curve postulates a negative relationship between the wage rate of workers and the regional unemployment rate. The standard approach renders the relationship between individual wages, $w_{i r t}$, and the regional unemployment rate, $u_{\mathrm{r} t}$, controlled by a set of individual characteristics $X_{1 \text { irt }}, X_{2 i r t}, \ldots, X_{\text {mirt }}$ as well as region and time fixed effects, $\alpha_{r}$, and $\alpha_{\text {ot }}$, respectively:

(1) $\log \left(w_{\text {irt }}\right)=\alpha_{r} \bullet+\alpha_{\bullet t}+\beta \cdot \log \left(u_{r t}\right)+\sum_{j=1}^{m} \delta_{j} \cdot x_{j i r t}+\varepsilon_{i r t}$

The parameter $\beta$ denotes the unemployment elasticity and the parameters are the regression coefficients of control variables like age, gender, education, industry and firm size. Finally, $\varepsilon_{i r t}$ is an idiosyncratic disturbance.

Competitive models of the labour market fail to explain the negative association between individual wages and regional unemployment (Blanchflower and Oswald 1995; Card 1995). Thus, the wage curve is based on non-competitive market structures. A negative linkage between unemployment and wages could be explained by the labour contract and union bargaining models. Although pacts of employment and competitiveness relieved wage agreements at the firm level in Germany (Seifert and Massa-Wirth 2005), collective bargaining is still dominant (Fitzenberger, Kohn and Lembcke 2013). However, collective agreements refer to the industrial, not to the regional level (Fitzenberger, Kohn and Lembcke 2013).

The efficiency wage hypothesis provides an explanation of wages that is not linked to a particular institutional setting. According to the model proposed by Shapiro and Stiglitz (1984), employers offer wage premiums to promote workers' efforts and avoid shirking. The higher the unemployment rate, the more difficult workers will find a new job in case of a dismissal. Against this backdrop, firms can afford to offer lower wage premiums in slack labour markets. Therefore, a negative link between regional unemployment and wages is expected. With the labour turnover model (Campbell and Orszag 1998) as a special variant of the efficiency wage hypothesis, the wage curve is drawn on fixed costs for recruiting and training. As these costs might be rather high, employers will accept a premium on top of the bill to keep current employees and discourage them to quit. Wage premiums will be lower in periods of economic downturns, where it is less likely that workers quit and find new jobs. 
Both the efficiency wage hypothesis and the labour turnover model can be adopted into a system of interacting regions (Longhi, Nijkamp and Poot 2006). The power of threat of shirking or quitting to workers is not only represented by local labour market conditions but also by the unemployment rate in proximate regions (Fingleton and Palombi, 2013). The regional dimension is introduced by monopsonistic competition. In view of commuting flows across regions, local labour markets cannot be longer treated as isolated entities. In the presence of spatial interactions among neighbouring territories, competition for workers takes place within and between proximate labour market areas. Thus, local wages $w_{\text {rt }}$ are determined by unemployment in the own and neighbouring regions, $u_{\mathrm{rt}}$ and $\operatorname{SL}\left(u_{\mathrm{r}}\right)$, after controlling for individual characteristics $X_{\mathrm{jtr}}$ and region and time fixed effects:

(2) $\log \left(w_{i r t}\right)=\alpha_{r} \bullet+\alpha_{\bullet t}+\beta \cdot \log \left(u_{r t}\right)+\beta * \cdot S L\left(\log \left(\left(u_{r t}\right)\right)+\sum_{j=1}^{m} \delta_{j} \cdot X_{j i r t}+\varepsilon_{i r t}\right.$

The spatial spillover unemployment elasticity of pay, $\beta^{*}$, measures the effect of the spatially weighted unemployment rate of proximate regions, $\operatorname{SL}\left(\log \left(\left(u_{r t}\right)\right)\right.$, on the own region's wage rate. The spillover variable $\operatorname{SL}\left(\log \left(\left(u_{r t}\right)\right)\right.$ is operationalized with the aid of a matrix of spatial weights $\Omega^{\star}$. Here, the contiguity concept is employed, where $\omega_{\mathrm{rs}}^{*}$ is set equal to 1 if the regions $r$ and $s, r \neq s$, share a common boundary and 0 otherwise. As arobustness check, we also use spatial weights corresponding to travel time between the regions. s. Using row-standardized weights $\omega_{\mathrm{rs}}$ (Anselin and Bera 1998, p. 243), the spatial lag of the unemployment rate can be written as

$$
\mathrm{SL}\left(\log \left(\left(\mathrm{u}_{\mathrm{rt}}\right)\right)=\sum_{\mathrm{s}=1}^{\mathrm{n}} \omega_{\mathrm{rs}} \cdot \log \left(\mathrm{u}_{\mathrm{st}}\right)\right. \text {. }
$$

\section{Global cointegration and spatial error correction}

The variables in the standard and spatial wage curve (1) and (2) are measured for different types of statistical units. While the wage $w_{\text {irt }}$ refers to individuals, the unemployment rate $u_{\mathrm{rt}}$ relates to regions. Adverse effects occur when workers in the same labour market share common components of variance reflected in explanatory variables and disturbances. In this case, the errors $\varepsilon_{\text {irt }}$ will be positively autocorrelated across individuals in the same labour market. Due to the common group effect, the standard error of the response coefficients will be downward biased (Moulton 1990). 
To account for the Moulton bias, usually individual aggregation is conducted when spatial effects come into play, regardless of the estimation strategy (Baltagi, Blien and Wolf 2012). Here the common group effect is addressed by averaging individualspecific variables over all workers in labour market $r$ in period $t$ :

(3) $\log \left(w_{r t}\right)=\alpha_{r \bullet}+\alpha_{\bullet t}+\beta \cdot \log \left(u_{r t}\right)+\beta * \cdot S L\left(\log \left(\left(u_{r t}\right)\right)+\sum_{j=1}^{m} \delta_{j} \cdot X_{j r t}+\varepsilon_{r t} \cdot\right.$

In this specification, the control variables of the spatial wage curve (3), $X_{1 r t}, X_{2 r t}, \ldots$, $X_{m r t}$, reflect observable regional characteristics. To account for omitted variables that are correlated across space, a spatially autocorrelated error process can be adopted:

(4) $\varepsilon_{\mathrm{rt}}=\rho \sum_{\mathrm{j}=1}^{m} \mathrm{~W}_{\mathrm{rs}} \cdot \varepsilon_{\mathrm{rt}}+v_{\mathrm{rt}}$

where $v_{\mathrm{rt}}$ is an i.i.d. innovation. The equations (3) and (4) constitute a fixed effects SLX panel model with spatially autocorrelated errors (FE-SLX-SEM model). For $\rho=0$ the FE-SLX panel model arises. The case $\beta^{\star}=0$ and $\rho=0$ typifies the standard FE panel model. ${ }^{4}$

Another problem will occur due to the endogeneity of the unemployment rate. From the standard FE panel model it is known that the unemployment elasticity will be downwardly biased and inconsistent in this case (Baltagi and Blien 1998; Baltagi, Baskaya and Hulago 2012). Baltagi and Blien (1998) show that the wage curve elasticity is indeed sensitive to endogeneity. To avoid the resulting bias, the regional unemployment rate should be instrumented with time lags of the unemployment rate and the control variables. Specifically, one- and two-period lags of the regional unemployment rate are chosen jointly with the contemporary and lagged control variables as instruments.

If the wage curve constitutes a long-run equilibrium relationship, the model (3) can be interpreted as a cointegrating equation between wages, unemployment and regional characteristics. By noting the autoregressive nature of wage bargaining, Blanchflower and Oswald (2005) view "the data as being characterized by dynamic fluctuations around a long-run wage curve".

In order to be cointegrated, at least two variables must share the highest order of integration. Panel unit root tests usually assume independent time series across the

\footnotetext{
${ }^{4} \mathrm{SLX}$ stands for spatial lag of one or more explanatory variables. For a taxonomy of spatial panel data models s. Elhorst (2014, pp. 37 with reference to p. 9).
} 
panel members. This assumption is particularly violated in spatial panels. Pesaran (2007) augmented the IPS test ${ }^{5}$ by adopting a common factor model for capturing cross-sectional dependence. By additionally accounting for serial dependence in form of an $A R(1)$ error process, the test equation for the variable $y$ without $a$ deterministic trend reads

(5) $\Delta y_{r t}=a_{r}+b_{r} \cdot y_{r, t-1}+c_{r} \cdot \bar{y}_{t-1}+d_{r 0} \cdot \Delta \bar{y}_{t}+d_{r 1} \cdot \Delta \bar{y}_{t-1}+e_{r} \cdot \Delta y_{r, t-1}+u_{r t} \cdot$

In this approach, the common factor is proxied by the cross-section mean $\bar{y}_{t}$ and its lagged value. For non-trended data the cross-sectionally augmented IPS test (CIPS test) already has satisfactory size and power for moderate values of $n$ and T. For trended data, however, the power of the test starts to raise with $n$ only for $T>30$.

Recent studies on the wage-unemployment nexus discovered not only the relevance of spatial effects but also a central role of wage inertia (Baltagi, Blien and Wolf 2009, 2012; García-Mainar and Montuenga-Gómez 2012; Ramos, Nicodemo and Sanroma 2015). Although Blanchflower and Oswald (1995) already pointed to error-correction models as suitable tools to distinguish between short run dynamics and a long-run equilibrium, studies usually introduce dynamics by adding lagged wages and unemployment rates. The notion of modelling inertia of wage adjustment by an error correction mechanism $(\mathrm{ECM})$ in a regional setting has been taken up by Ammermüller et al. (2012). However, spatial effects are usually neglected. While adjustments to equilibrium wages within the regions are considered, the between effects are excluded.

Recently, Beenstock and Felsenstein $(2010,2015)$ extended the standard panel error correction model by "spatializing" the adjustment to equilibrium. The error-correction mechanism is assumed to work not only within but also between the regions. While the effectiveness of local error correction is examined by the coefficient of the lagged residuals $E_{\mathrm{r}, \mathrm{t}-1}$ from the long-run relationship, the presence of spatial correction is assessed by evaluating the coefficient of the lagged residuals of neigbouring regions $E_{\mathrm{r}, \mathrm{t}-1}^{\star}$. The spatial error correction model (SpECM) additionally captures changes in labour market conditions in the neighbourhood regions. The dynamic counterpart of the cointegrating relationship (3) reads

\footnotetext{
${ }^{5}$ The IPS test is a test on the presence of a unit root in heterogenous panels without accounting for crosssectional dependence (Im, Pesaran and Shin 2003).
} 
(6) $\Delta\left(\log \left(\mathrm{w}_{\mathrm{rt}}\right)\right)=\alpha+\phi_{1} \cdot \Delta\left(\log \left(\mathrm{w}_{\mathrm{r}, \mathrm{t}-1}\right)\right)+\gamma_{0} \Delta\left(\log \left(\mathrm{u}_{\mathrm{rt}}\right)\right)+\gamma_{1} \Delta\left(\log \left(\mathrm{u}_{\mathrm{r}, \mathrm{t}-1}\right)\right)+\gamma_{0}^{*} \Delta \mathrm{SL}\left(\log \left(\mathrm{u}_{\mathrm{rt}}\right)\right)$

$+\gamma_{1}^{*} \Delta S L\left(\log \left(u_{r, t-1}\right)\right)+\sum_{j=1}^{m} \theta_{j 0} \Delta X_{j r t}+\sum_{j=1}^{m} \theta_{j 1} \Delta X_{j r, t-1}+\alpha E C_{r, t-1}+\alpha^{*} \cdot E_{r, t-1}^{*}+v_{r t}$

based on an autoregressive distributed lag model (ADL) of order 2 in the dependent and explanatory variables. For local error correction to be effective, the adjustment coefficient $\alpha$ should be negative. In this case, previous deviations from local equilibrium wages are partially reduced in the following periods. Spatial error correction relates to equilibrium adjustment across space. A positive sign of the error correction coefficient $\alpha^{*}$ indicates the effectiveness of an adjustment process between proximate regions. Both coefficient $\alpha$ and $\alpha^{*}$ measure the speed of adjustment toward long-run equilibrium. For $-1 \leq \alpha<0$ and $0<\alpha^{*} \leq 1$ the system is said to be globally cointegrated. In case of a negative spatial adjustment coefficient $\alpha^{*}$, above-equilibrium wages in the neighbouring regions would exert a downward pressure on local wages. The borderline case $\alpha=\alpha^{*}=1$ indicates full adjustment within one period. In the special case $\alpha=\alpha^{*}=0$, the spatial error correction model (SpECM) turns into a spatial vector autoregression as an adequate dynamic modelling framework for stationary variables.

In the SLX fixed effects panel model with spatially autocorrelated errors, OLS produces inefficient estimates of the regression coefficients (Anselin 1988, p. 59; LeSage and Pace 2009, p. 62). By taking the Jacobian determinant into account, maximum likelihood (ML) may provide efficiency gains (cf. LeSage and Pace 2010, p. 359). This also holds for the ML approach applied to the spatial panel model with fixed effects (see e.g. Elhorst 2010, p. 393). The problem of a simultaneity bias in the case of reverse causality is usually adressed by instrumental variables (IV).

However, the proposed methods are not optimally designed for nonstationary data. In a spatial analysis the number of regions is usually fixed as the spatial units are not sampled (Elhorst 2014, pp. 55-56). Suppose the observable variables of a spatial panel model are integrated of order one $(I(1))$ and cointegrated. In this case, the nonstationary regressors are asymptotically independent from the stationary I(0) error term (Beenstock and Felsenstein 2015). Although OLS estimators are superconsistent, the simultaneity bias is still present in finite samples. Given the fixed number of regions, the finite sample bias depends just as asymptotics on the number 
of periods, T. To address this bias, potentially endogenous regressors may be instrumented.

In their global cointegration analysis of Israel's housing market, Beenstock and Felsenstein (2015) provide arguments that the endogeneity bias is negligible with a sample size of $\mathrm{T}=24$ for annual data. In the 2010 paper they use OLS with $\mathrm{T}=18$ without any instrumentation in estimating the long-run relationship and the SpEC model. However, up to now, reliable knowledge on finite sample properties of panel cointegration is not available. In their analysis of productivity growth across Chinese provinces, Mitze and Oezyurt (2014) account for the endogenity of the spatially lagged dependent variable by applying the ML approach of Lee and Yu (2010a) even with a larger sample size of $\mathrm{T}=33$. Kosfeld and Dreger (2017) apply the ML-IV method to allow for the simultaneity bias in studying the West German wage curve with an effective sample size of $\mathrm{T}=15$.

In this paper, the panel cointegration analysis of the East German wage curve is conducted for both 77 administrative and 33 functional regions over a 16-year period. By making use of one- and two period lagged variables to account for partial adjustment patterns the effectively number of observations per spatial unit reduces to $T=14$. With this number of time periods the endogeneity bias deserves more attention than in the aforementioned studies. For that reason, the long-run wage curve is estimated by applying the ML and OLS methods on a set of nonstationary variables with an instrumented unemployment rate as a potentially endogenous regressor. Besides the one- and two-period lagged unemployment rate, contemporaneous and lagged control variables are used as instruments. To check the extent of a simultaneity bias, the estimation is also performed without instrumentation.

In the SpEC model the log difference of the wage rate is regressed on one-period lagged first- and second-order differenced explanatory variables and local and spatial error correction (EC) terms. As all differenced variables are stationary the simultaneity bias matters even asymptotically. Thus, the use the instrumental variables (IV) technique is invariably indicated here in the presence of endogenous regressors. Again the consequences of instrumentation on relevant parameter estimates is checked. 


\section{Defining regional areas}

In almost all studies, panel data on small administrative regions like districts are employed to estimate the wage curve. As these areas usually do not constitute separate labour markets, spatial effects are expected to be present. However, administrative units do not adequately reflect the scale of the underlying spatial process. Thus, in analysing spatial data from administrative regions, substantial spillovers will be confounded by error dependence evoked due to measurement problems. They can be avoided by using functional defined areas. Labour market regions are characterized by commuter flows, where the commuting distance can serve as a delimiter (cf. Kosfeld and Werner 2012; Kropp and Schwengler 2016). We particularly draw on the factor analytic approach of Kosfeld and Werner (2012) who extract labour market regions from the correlation structure of commuter flows across German districts. To improve the connectedness of the functional areas, the commuting distance is considered as a constraint. The commuting distance within employment areas is limited to politically acceptable thresholds between 45 to 60 minutes travel time dependent on the attractiveness of the centres. In this way, 33 labour market regions consisting of one up to six districts are extracted from the 77 East German districts (NUTS-3 regions).

Unemployment rates are measured for both districts and employment agencies. The administrative districts are the smallest spatial units for which unemployment rates are reported. Because of their embeddedness in the competences and responsibilities of the public employment administration (Hilbert 2008, pp. 73-74), regions corresponding to employment agencies do not share the characteristics of functional regions (Kropp and Schwengler 2016). Yearly panel data on unemployment for the 77 East German NUTS-3 regions are available from the Labour Market Statistics of the German Federal Employment Agency (BA). Unemployment rates for the functional labour market regions are obtained through averaging the corresponding unemployment rates in the districts, where labour force weights are used.

The official statistics provides different indicators for wages. The Regional Database of the German Federal Statistical Office reports gross wages and salaries per year. By dividing through the number of employees, annual wages per worker are obtained. However, without calculating full-time equivalents, full time and part time 
occcupations will be mixed. Daily wages drawn from the Sample of Integrated Labour Market Biographies (SIAM) of Integrated Employment Biographies (IEB) of the Institute for Employment Research (IAB) relate to full-time employees with hourly wages of more than six Euro who are subject to social security contributions.

In investigating the impacts of economic conditions on wages, individual characteristics like vocational education, experience and gender have to be included (cf. Heckman, Lochner and Todd 2003). In addition, working time, branch and firm size may influence hourly wages. Data on the control variables is provided at the district level by the Federal Employment Agency. The variables at the level of functional areas are obtained by aggregation. Table 1 gives an overview of the regional characteristics. Their potential relevance for wage determination is also outlined.

Table 1: Regional characteristics

\begin{tabular}{|c|c|c|c|}
\hline Type of control & Variable & Indicator & Relevance \\
\hline - Experience & $\begin{array}{l}\text { Share of youn- } \\
\text { ger workers } \\
\text { Share of elder } \\
\text { workers }\end{array}$ & $\begin{array}{l}\text { Share of employ- } \\
\text { yees younger } \\
\text { than } 30 \text { years } \\
\text { Share of employ- } \\
\text { yees of } 50 \text { years } \\
\text { or older }\end{array}$ & $\begin{array}{l}\text { Less work experience; } \\
\text { cognitive abilities } \\
\text { (speed and memory) } \\
\text { More work experience; } \\
\text { less physical strength; } \\
\text { cognitive abilities (vo- } \\
\text { cabulary size, verbal } \\
\text { abilities) }\end{array}$ \\
\hline $\begin{array}{l}\text { - Vocational } \\
\text { education }\end{array}$ & $\begin{array}{l}\text { Share of high } \\
\text { qualified } \\
\text { workers }\end{array}$ & $\begin{array}{l}\text { Share of emplo- } \\
\text { yees with an } \\
\text { academic degree }\end{array}$ & $\begin{array}{l}\text { Benefits of higher edu- } \\
\text { cation („education } \\
\text { pays“) }\end{array}$ \\
\hline - Gender & $\begin{array}{l}\text { Share of fe- } \\
\text { male workers }\end{array}$ & $\begin{array}{l}\text { Share of female } \\
\text { workers }\end{array}$ & $\begin{array}{l}\text { Higher labour supply } \\
\text { elasticity; less em- } \\
\text { ployed in sectors with } \\
\text { high entry/exit costs }\end{array}$ \\
\hline - Working time & $\begin{array}{l}\text { Share of part- } \\
\text { time workers }\end{array}$ & $\begin{array}{l}\text { Share of part- } \\
\text { time workers }\end{array}$ & $\begin{array}{l}\text { Less bargaining power } \\
\text { (high share in unfa- } \\
\text { vourable business } \\
\text { conditions) }\end{array}$ \\
\hline - Firm size & Firm size & $\begin{array}{l}\text { Average number } \\
\text { of employees per } \\
\text { firm in full-time } \\
\text { equivalents }\end{array}$ & $\begin{array}{l}\text { Small firms have less } \\
\text { monitoring costs and } \\
\text { offer different employ- } \\
\text { ment opportunities } \\
\text { than large firms }\end{array}$ \\
\hline $\begin{array}{l}\text { - Sectoral } \\
\text { composition }\end{array}$ & Industry sector & $\begin{array}{l}\text { Share of } \\
\text { industrial em- } \\
\text { ployees }\end{array}$ & $\begin{array}{l}\text { Sectoral wage diffe- } \\
\text { rentials }\end{array}$ \\
\hline
\end{tabular}




\section{Empirical Analysis}

\subsection{Spatial dependence and nonstationarity}

For testing nonstationarity properties in spatial panel data, cross-sectional dependencies have to be taken into account. Spatial autocorrelation of georeferenced variables can be assessed with the Moran test (Anselin 1988, pp. 101). Here we focus on spatial autocorrelation of the key variables, namely wages and unemployment. Figure 1 reveals striking differences in the strength of spatial dependence between both variables.

Figure 1: Moran coefficients of the wage and the unemployment rate

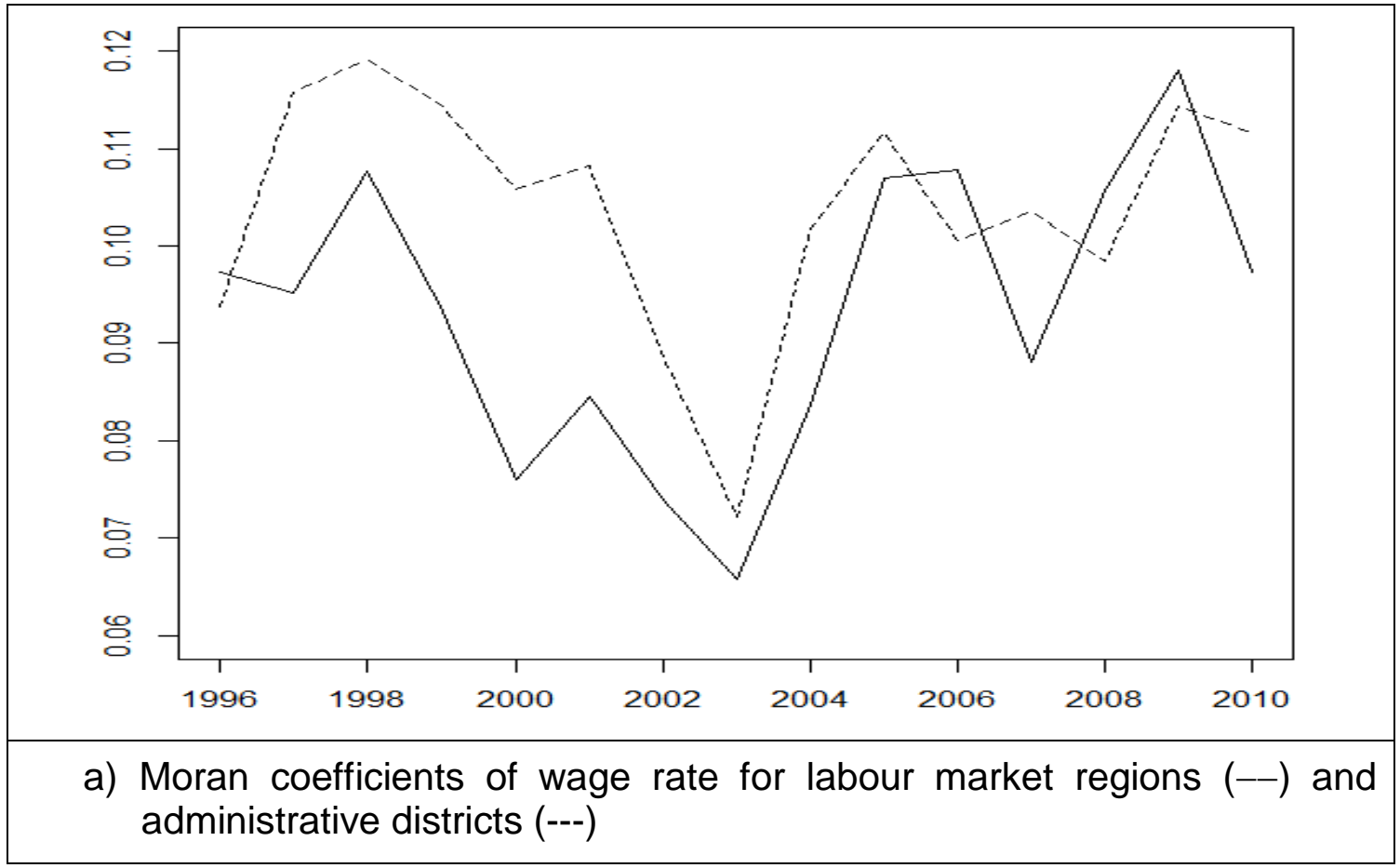




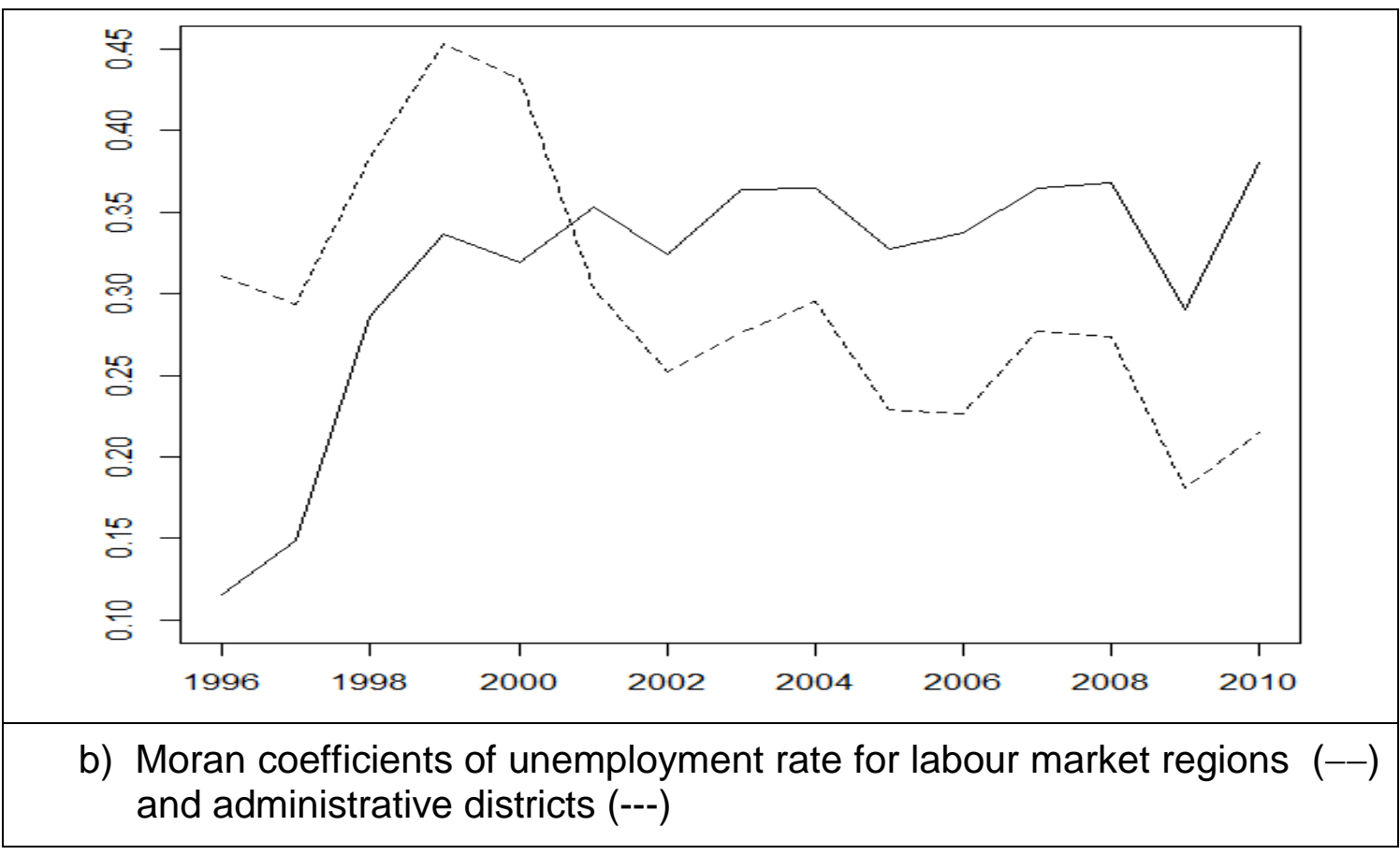

The annual Moran coefficients of the wage rate fluctuate closely around a mean value of 0.10. In most years Moran's I values are slightly lower for labour market regions. However, in none of the cases significant spatial autocorrelation occurs at the $5 \%$ level, In six out of fifteen years the null hypothesis of spatial randomness cannot be rejected for both disaggregations at the $10 \%$ level of significance. Weak significant spatial dependence of the wage rate is primarily established at the beginning and end of the period of investigation.

Strong spatial dependence is disclosed for the unemployment rate in both regional disaggregations with a mean Moran's I value of 0.30 . With the exception of the first two years.the Moran coefficient is significant at the $1 \%$ level. However, two different trends are evident in the regional structures. While a downward trend in spatial dependence is observed for NUTS-3 regions, a slight upward trend is apparent for functional areas. This gives an indication that the strength of spatial interaction between neighbouring labour markets is increasingly underestimated for the administrative breakdown.

Next, we examine the nonstationarity properties by panel unit roots tests. Since time series in spatial panels are usually contemporaneously correlated, the conventional IPS test may provide misleading indications. Here nonstationarity characteristics are checked on the basis of Pesaran's (2007) panel unit root test (CIPS test) that abandons the assumption of cross-sectional independence by adopting a common 
factor approach. While the test equation (5) is used with the intercept in testing for a unit root in the unemployment rate and the control variables, a linear trend is included as additional component in case of the wage rate.

Table 2: Cross-sectionally augmented IPS test (CIPS test)

\begin{tabular}{lllll}
\hline & \multicolumn{2}{l}{ Administrative districts } & \multicolumn{2}{l}{ Labour market regions } \\
\hline & Level & Difference & Level & Difference \\
\hline Log wage rate & $-2.9577^{\star \star}$ & $-3.0756^{\star \star}$ & $-3.0106^{\star}$ & $-3.1183^{\star \star}$ \\
Log unemployment rate & -1.9864 & $-2.8221^{\star \star}$ & -1.9731 & $-2.5778^{\star \star}$ \\
Share of younger workers & -1.4984 & $-2.3983^{\star \star}$ & -1.9170 & $-2.6075^{\star \star}$ \\
Share of elder workers & -1.7279 & $-2.4792^{\star \star}$ & -1.7455 & $-2.4696^{\star \star}$ \\
Share of high qualified workers & -1.4850 & $-2.5720^{\star \star}$ & -1.6400 & $-2.5215^{\star \star}$ \\
Share of female workers & -1.9707 & $-2.3517^{\star \star}$ & $-2.2206^{\star}$ & $-2.0854^{(\star)}$ \\
Share of part-time workers & $-2.4114^{\star \star}$ & $-2.7716^{\star \star}$ & $-2.4313^{\star \star}$ & $-2.6586^{\star \star}$ \\
Share of industrial sector & -1.8964 & $-2.3434^{\star \star}$ & -1.7794 & -2.0227 \\
Average size of enterprises & -2.0264 & $-2.6134^{\star \star}$ & $-2.3236^{\star}$ & $-2.4674^{\star \star}$ \\
Square aver. size of enterprises & -2.0265 & $-2.6025^{\star \star}$ & $-2.3227^{\star}$ & $-2.4531^{\star \star}$ \\
\hline
\end{tabular}

Note: ${ }^{*} 1 \%$ significance level, $* 5 \%$ significance level, ${ }^{(*)} 10 \%$ significance level

Table 2 reports the results of the CIPS tests for the key and control variables of the wage curve. The unit root hypothesis is rejected for the wage rate at the $5 \%$ level of significance, but not at the $10 \%$ level. As the wage rate includes a trend, the power of the test is low for the given sample size. For the unemployment rate, the unit root cannot be rejected. For the control variables, the unit root hypothesis is accepted for all but one case at any reasonable level of significance with district data. For labour market regions, the outcomes for the control variables are mixed. However, the first differenced series of nearly all tested variables are found to be stationary. Nonsignificance of the first differences only occurs for the industrial share. In view of the significant result for administrative districts, this failure of detection stationarity for functional areas may be ascribed to the small sample size. Therefore, a cointegration relationship may exist among the variables under study.

\subsection{Long-run wage curve and spatial spillovers}

Econometric analysis of the relationship between the wage and unemployment rate starts with estimating and testing for a potential East German long-run wage curve leaving aside spatial effects. Table 3 displays the estimation results of the fixed effects model without and with instrumentation of the unemployment rate for both levels of spatial disaggregation. In both cases the Hausman test clearly rejects the 
random effects specification in favour of the fixed effects model. Region and time fixed effects prove to be highly significant.

Table 3: Fixed effect (FE) models of the East German wage

\begin{tabular}{|c|c|c|c|c|}
\hline & \multicolumn{2}{|c|}{ Administrative districts } & \multicolumn{2}{|c|}{ Labour market regions } \\
\hline & FE (ML) & FE (ML-IV) & FE (ML) & FE (ML-IV) \\
\hline $\log (u)$ & $\begin{array}{l}-0.0086 \\
(0.0080)\end{array}$ & $\begin{array}{l}-0.0056 \\
(0.0077)\end{array}$ & $\begin{array}{l}-0.0356^{\star *} \\
(0.0131)\end{array}$ & $\begin{array}{l}-0.0328 * \star \\
(0.0118)\end{array}$ \\
\hline Young & $\begin{array}{l}-0.0911 \\
(0.0862\end{array}$ & $\begin{array}{l}-0.1090 \\
(0.0863)\end{array}$ & $\begin{array}{l}-0.1512 \\
(0.1403)\end{array}$ & $\begin{array}{l}-0.1909 \\
(0.1394)\end{array}$ \\
\hline Old & $\begin{array}{l}0.1059(*) \\
(0.0620)\end{array}$ & $\begin{array}{l}0.1171^{(*)} \\
(0.0620)\end{array}$ & $\begin{array}{l}0.2277^{\star *} \\
(0.0792)\end{array}$ & $\begin{array}{l}0.2379 * * \\
(0.0793)\end{array}$ \\
\hline Qual & $\begin{array}{l}0.5995^{\star \star} \\
(0.1235)\end{array}$ & $\begin{array}{l}0.6028 \text { ** } \\
(0.1236)\end{array}$ & $\begin{array}{l}0.5111^{* \star} \\
(0.1569)\end{array}$ & $\begin{array}{l}0.4312^{\star *} \\
(0.1569)\end{array}$ \\
\hline female & $\begin{array}{l}0.0700 \\
(0.0836)\end{array}$ & $\begin{array}{l}0.0583 \\
(0.0838)\end{array}$ & $\begin{array}{l}-0.0948 \\
(0.1406)\end{array}$ & $\begin{array}{l}-0.0642 \\
(0.1419)\end{array}$ \\
\hline part-time & $\begin{array}{l}-0.3756^{\star *} \\
(0.0653)\end{array}$ & $\begin{array}{l}-0.3835^{\star *} \\
(0.0653)\end{array}$ & $\begin{array}{l}-0.2758^{\star *} \\
(0.1006)\end{array}$ & $\begin{array}{l}-0.2562^{\star} \\
(0.1009)\end{array}$ \\
\hline industry & $\begin{array}{l}0.0490 \\
(0.0498)\end{array}$ & $\begin{array}{l}0.0535 \\
(0.0498)\end{array}$ & $\begin{array}{l}-0.2788^{\star *} \\
(0.0846)\end{array}$ & $\begin{array}{l}-0.2323^{\star *} \\
(0.0841)\end{array}$ \\
\hline Size & $\begin{array}{l}0.0564^{\star *} \\
(0.0060)\end{array}$ & $\begin{array}{l}0.0570 \text { ** } \\
(0.0060)\end{array}$ & $\begin{array}{l}0.0734^{\star *} \\
(0.0130)\end{array}$ & $\begin{array}{l}0.0783^{* *} \\
(0.0133)\end{array}$ \\
\hline size $^{2}$ & $\begin{array}{l}-0.0017^{\star *} \\
(0.0002)\end{array}$ & $\begin{array}{l}-0.0017^{\star *} \\
(0.0002)\end{array}$ & $\begin{array}{l}-0.0024^{\star *} \\
(0.0005)\end{array}$ & $\begin{array}{l}-0.0026 \text { ** } \\
(0.0006)\end{array}$ \\
\hline Region FE & yes & Yes & Yes & Yes \\
\hline Time FE & yes & Yes & Yes & Yes \\
\hline $\mathrm{N}$ & 77 & 77 & 33 & 33 \\
\hline $\mathrm{T}$ & 14 & 14 & 14 & 14 \\
\hline SER & 0.0173 & 0.0173 & 0.0132 & 0.0132 \\
\hline $\mathrm{R}^{2}$ & 0.9858 & 0.9857 & 0.9934 & 0.9934 \\
\hline Hausman & $1058.1^{* *}$ & $1043.3^{\star \star}$ & $539.8 * *$ & $650.9 * *$ \\
\hline Scaled LM CD & $35.002^{* *}$ & $34.663^{\star \star}$ & $14.854^{\star \star}$ & $15.465^{\star \star}$ \\
\hline
\end{tabular}

Although the regression coefficient of the unemployment rate has the expected negative sign in all cases, it is only significant for labour market regions. ${ }^{6}$. No substantive differences arise from the instrumentation of the unemployment rate in this setting. With an absolute value of roughly 3.5\%, the strength of responsiveness of wages to changes in the own unemployment rate is about one third of that stated by Blanchflower and Oswald's empirical law (Blanchflower/Oswald 1994). However, the high t-value of about 2.7 indicates that it is precisely estimated. Most control variables turn out to be significant. The estimation result reveals the problem with a

\footnotetext{
${ }^{6}$ In panel data analysis, usually the Gauß test (z-test) is applied for assessing significance. This ignores the fact that the estimated coefficients follow nonstandard distributions in the case of nonstationarity. Traditional significance tests on the regression coefficients in panel models used in established toolboxes and programs like Matlab, R, Stata and EViews should be interpreted with caution.
} 
purely administrative delineation. Spatial processes are not adequarely reflected at a local scale. Regional actors do not only consider labour market conditions within a narrowly prescribed region but within larger travel-to-work areas.

The influence of labour market conditions within an acceptable commuting distance on wages may lead one to expect that spatial unemployment spillovers may be present at the district level. The misspecification of the district wage curve is also indicated by the LM spatial autocorrelation test. The local version of Breusch and Pagan's scaled LM test (Croisssant and Millo 2008) clearly rejects the null hypothesis of spatial randomness irrespective of whether the unemployment rate is instrumented or not. Although the test statistic is more than halved with functional areas, regional spillovers still remain highly significant.

To capture cross-sectional dependencies, the spatially lagged unemployment rate is introduced into the wage curve. Table 4 shows that neither a direct nor a spillover effect of the unemployment rate can be established for administrative districts. This outcome may appear somewhat strange in view of a highly significant estimate of the unemployment elasticity in travel-to-work regions. However, main commuter flows of surrounding districts may not necessary be aligned towards the region under consideration. Moreover, travel-to-work areas are not only composed of first-order neighbours but also of higher-order neighbours. Thus, the sum of direct and spillover effects measured at the level of administrative districts can deviate substantially from the direct unemployment impacts ascertained for functional labour market regions. This distortion is inevitable inherent with the use of administrative regions in spatial econometric analysis although to different degrees. Spillovers of labour market conditions on wages are only disclosed by assembling the centres of production with the related commuter belts. 
Table 4: FE-LX-SEM models of the East German wage

\begin{tabular}{|c|c|c|c|c|}
\hline & \multicolumn{2}{|c|}{ Administrative districts } & \multicolumn{2}{|c|}{ Labour market regions } \\
\hline & FE-LX-SEM & FE-LX(IV)-SEM & FE-LX-SEM & FE-LX(IV)-SEM \\
\hline \multirow[t]{2}{*}{$\log (u)$} & -0.0054 & 0.0074 & $-0.0378 * \star$ & $-0.0317^{\star \star}$ \\
\hline & $(0.0078)$ & $(0.0076)$ & (0.0129) & $(0.0118)$ \\
\hline \multirow[t]{2}{*}{$\mathrm{W} \cdot \log (\mathrm{u})$} & $-0.0200)$ & -0.0074 & 0.0061 & $-0.0314^{(*)}$ \\
\hline & $(0.0131)$ & $(0.0128)$ & $(0.0224)$ & (0.0185) \\
\hline \multirow[t]{2}{*}{$W \cdot \varepsilon$} & 0.0497 & 0.0651 & -0.2870 ** & $-0.3495^{\star \star}$ \\
\hline & $(0.0426)$ & $(0.0424)$ & $(0.0710)$ & $(0.0709)$ \\
\hline \multirow[t]{2}{*}{ Young } & -0.0762 & -0.0948 & $-0.2589 *$ & $-0.3181^{* *}$ \\
\hline & $(0.0825)$ & $(0.0827)$ & $(0.1257)$ & $(0.1215)$ \\
\hline \multirow[t]{2}{*}{ Old } & $0.1298 *$ & $0.1336 *$ & $0.1312^{(*)}$ & $0.1332^{*}$ \\
\hline & $(0.0605)$ & $(0.0603)$ & $(0.0680)$ & $(0.0655)$ \\
\hline \multirow[t]{2}{*}{ Qual } & $0.6044^{* *}$ & $0.6187^{* *}$ & $0.5129 * *$ & $0.5019 * *$ \\
\hline & (0.1181) & (0.1183) & (0.1481) & $(0.1448)$ \\
\hline \multirow[t]{2}{*}{ Female } & 0.0889 & 0.0741 & -0.1850 & -0.1339 \\
\hline & $(0.0799)$ & $(0.0803)$ & $(0.1312)$ & $(0.1291)$ \\
\hline \multirow[t]{2}{*}{ part-time } & $-0.3880 * \star$ & $-0.3990 * *$ & $-0.2343^{\star \star}$ & $-0.2137^{\star}$ \\
\hline & $(0.0624)$ & $(0.0626)$ & $(0.0905)$ & $(0.0884)$ \\
\hline \multirow[t]{2}{*}{ Industry } & 0.0547 & 0.0599 & $-0.2898^{\star \star}$ & $-0.2480 * *$ \\
\hline & $(0.0474)$ & $(0.0474)$ & (0.0757) & $(0.0737)$ \\
\hline \multirow[t]{2}{*}{ Size } & 0.0570 ** & $0.0576^{\star \star}$ & $0.0663^{* *}$ & $0.0710^{\star \star}$ \\
\hline & $(0.0057)$ & $(0.0057)$ & (0.0119) & $(0.0120)$ \\
\hline \multirow[t]{2}{*}{$\operatorname{size}^{2}$} & $-0.0017^{\star *}$ & $-0.0017^{* *}$ & $-0.0022^{\star \star}$ & $-0.0024^{\star *}$ \\
\hline & $(0.0002)$ & $(0.0002)$ & $(0.0005)$ & $(0.0005)$ \\
\hline Region FE & Yes & Yes & Yes & yes \\
\hline Time FE & Yes & Yes & Yes & yes \\
\hline $\mathrm{N}$ & 77 & 77 & 33 & 33 \\
\hline $\mathrm{T}$ & 14 & 14 & 14 & 14 \\
\hline SER & 0.0269 & 0.0269 & 0.0133 & 0.0133 \\
\hline Pseudo- $\mathrm{R}^{2}$ & 0.9858 & 0.9858 & 0.9934 & 0.9934 \\
\hline
\end{tabular}

Based on functional regions a direct unemployment elasticity of 3 per cent is estimated by instrumenting the unemployment rate. This is somewhat lower in absolute terms than the estimated elasticity without instrumentation. Unemployment spillovers on wages are only revealed by IV estimation. Although the strength of both the direct and indirect effect effect are fairly identical, the weak significance of the latter indicates its greater variability. This probably reflects different intensities of interactions across regional labour markets.

In order to establish the existence of a long-run relationship between wages and regional unemployment, all panel regressions are run with region and time fixed effects. Most control variables are significant with the expected sign. A high wage level is especially traced to high shares of experienced and qualified workers. Moreover, wages tend to rise with increasing firm size up to a turning point of about 
30 employees. Regions with high shares of manufacturing and part-time workers are accompanied by low wages. By accounting for endogeneity of the unemployment rate, a weak negative effect is found for the share of young, unexperienced workers. The downward pressure of higher shares of female workes on wages is not statisticaly significant. This also applies to spatial lags of the control variables. However, omitted spatially autocorrelated variables are captured by a spatial autoregressive error process. The highly significant estimate of the autoregressive parameter means that internal shocks are not restricted to regional boundaries. At the same time, the adoption of a spatial autoregressive error process is accompanied by a higher precision of the estimated regression coefficients.

A lower responsiveness of wages to labour market conditons in East Germany is also reported by other studies. Our IV estimate falls slightly below the spatial first difference 2SLS estimate of -0.039 by Elhorst, Blien and Wolf (2007) in absolute terms. The authors do not find an East German wage curve with standard panel models.

\subsection{Spatial error-correction model and dynamic spatial wage curve}

The spatial error-correction model (SpEM) provides a device for testing local and spatial cointegration in the wage curve. The tests are based on the introduction of own and neighbouring regions' equilibrium deviations form the long-run wage curve. According to whether one or both mechanisms exist, local, spatial or global cointegration of the East German wage curve is inferred. The spatial error correction model for East Germany emerges when dynamic effects are combined with the equilibrium relationship.

Table 5 shows the estimated regression coefficients of the local and spatial error correction terms, $\mathrm{EC}_{\mathrm{t}-1}$ and $\mathrm{W} \cdot \mathrm{EC}_{\mathrm{t}-1}$, along with short-run changes of the explanatory variables. Nonsignificant short-run effects on changes in wages are suppressed. Regardless of instrumentation, the significantly negative error correction term $\mathrm{EC}_{\mathrm{t}-1}$ indicates the presence of local error correction. Conditional to regional characteristics, almost 35 percent of long-run wage imbalances from own region's equilibrium are corrected within a year. By contrast, a spatial error-correction mechanism is not in force. Equilibrium deviations will only be corrected in case of a positive sign of the regression coefficient of the error correction term $\mathrm{W} \cdot \mathrm{EC}_{\mathrm{t}-1}$. 
However, its significant and negative sign actually suggests that wage diseqilibria across neighbouring regions will not be reduced but increase over time. Thus, after controlling for regional characteristics, wages and unemployment are locally but not globally cointegrated.

Table 5: Spatial error correction model (SpEC)

\begin{tabular}{|c|c|c|c|c|}
\hline & \multicolumn{2}{|c|}{ SpECM } & \multicolumn{2}{|c|}{ SpECM IV } \\
\hline & Coefficients & Stand. Errors & Coefficients & Stand. Errors \\
\hline Intercept & $0.0153^{* \star}$ & 0.0009 & $0.0152 * \star$ & 0.0009 \\
\hline$\Delta \mathrm{W} \log \left(\mathrm{u}_{\mathrm{t}}\right)$ & $0.0461^{\star \star}$ & 0.0092 & $0.0332 * *$ & 0.0088 \\
\hline$E_{t-1}$ & $-0.3466^{\star *}$ & 0.0429 & $-0.3425^{\star \star}$ & 0.0442 \\
\hline$W E C_{t-1}$ & $-0.2435^{\star \star}$ & 0.0903 & $-0.2202^{*}$ & 0.0937 \\
\hline$\Delta$ young $_{\mathrm{t}}$ & $-0.4438^{* *}$ & 0.1128 & $-0.5068^{\star *}$ & 0.1129 \\
\hline$\Delta$ old $_{\mathrm{t}}$ & $0.2540 * \star$ & 0.0837 & $0.2188^{\star *}$ & 0.0844 \\
\hline$\Delta$ qual $_{\mathrm{t}}$ & $-0.8787^{\star *}$ & 0.2394 & $-0.7519 * \star$ & 0.2405 \\
\hline$\Delta$ part-time $_{\mathrm{t}}$ & $-0.1853^{*}$ & 0.0772 & $-0.2055^{\star *}$ & 0.0777 \\
\hline & $\mathrm{N}$ & 33 & $\mathrm{~N}$ & 33 \\
\hline & $\mathrm{T}$ & 13 & $\mathrm{~T}$ & 13 \\
\hline & SER & 0.0105 & SER & 0.0106 \\
\hline & $\mathrm{R}^{2}$ & 0.2453 & $\mathrm{R}^{2}$ & 0.2302 \\
\hline & $F$ & $19.546^{\star *}$ & $\mathrm{~F}$ & $17.278^{\star \star}$ \\
\hline
\end{tabular}

Table 5 additionally conveys information about which variables will induce short-run changes in the wage rate. Previous wage changes do not prove to be significant. In the short-run, changes in employment conditions in neighbouring labour markets significantly affect the adjustment of wages. Moreover, it is shown that wage changes are partly attributed to variations in regional characteristics. Significant short-run effects result from changes in the shares of younger and older workers, highly qualified employees and part-time workers. If the spatial error correction model is estimated with instruments, similar results are obtained.

\section{Choice of spatial weights matrix and sensitivity analysis}

The analysis presented above reveals the relevance of using functionally defined areas for establishing the relationship between wages and unemployment across space. With purely administrative regions, no wage curve can be detected for East Germany. Spatial effects are identified by adopting the contiguity approach for labour market regions. As a simulation study of Stakhovych and Bijmolt (2008) suggests, the choice of the spatial weights matrix may particularly affect the probability of a recovery of the 'true' model and the accuracy of the estimated regression 
coefficients. While the effects on the accuracy is found to be not very sensitive to the type of weights matrix for low spatial parameter values, they are much more sensitive for higher values. This seems in contrast to LeSage and Pace (2014) who find little theoretical support for marked differences in inference. However, LeSage and Pace (2014) do not rule out the possibility that different matrix choices have an impact on the results (see also Wang, Kockelman and Wang 2013).

Here we scrutinize the sensitivity of the results with respect to contiguity and distance-based spatial weights matrices. Because the physical and geographical distances do not reflect the costs of overcoming space, distance-based weights are formed using travel time between the regional centres. Regional centres are usually represented by the largest independent city or distríct town in the labour market regions. As full inverse distances will average out the positive spatial dependence between proximate regions (see also Longhi et al. 2006), travel time between regional centres is varied from 60 to 120 minutes. $^{7}$

Table 6: Sensitivity of the lon-run wage curve on choice of spatial weights matrix

\begin{tabular}{|l|l|l|l|l|l|l|}
\hline & Contiguity & $60 \mathrm{~min}$. & $75 \mathrm{~min}$. & $90 \mathrm{~min}$ & $105 \mathrm{~min}$ & $120 \mathrm{~min}$. \\
\hline $\log \left(\mathrm{u}_{\mathrm{t}}\right)$ & $-0.0317^{\star \star}$ & $-0.0268^{\star}$ & $-0.0322^{\star \star}$ & $-0.0290^{\star}$ & $-0.0299^{\star}$ & $-0.0314^{\star \star}$ \\
& $(0.0118)$ & $(0.0110)$ & $(0.0116)$ & $(0.0118)$ & $(0.0118)$ & $(0.0118)$ \\
\hline W $\log \left(\mathrm{u}_{\mathrm{t}}\right)$ & $\left.-0.0314^{\star \star}\right)$ & $-0.0472^{\star \star}$ & -0.0199 & -0.0298 & -0.0172 & -0.0153 \\
& $(0.0185)$ & $(0.0126)$ & $(0.0159)$ & $(0.0190)$ & $(0.0211)$ & $(0.0237)$ \\
\hline $\mathrm{W} \cdot \varepsilon$ & $-0.3495^{\star \star}$ & 0.0040 & $-0.2005^{\star \star}$ & $-0.2815^{\star \star}$ & $-0.2629^{\star}$ & $-0.2231^{\star}$ \\
& $(0.0709)$ & $(0.0421)$ & $(0.0565)$ & $(0.0822)$ & $(0.0962)$ & $(0.1101)$ \\
\hline $\log \mathrm{Lik}$ & 622.5 & 618.3 & 616.9 & 617.4 & 614.6 & 613.2 \\
\hline
\end{tabular}

IV estimators for the direct and indirect unemployment elasticity as well as for the autoregressive parameter of the distúrbances are shown for the first-order contiguity matrix and five travel time-based weights matrices in Table 6. Irrespective of the choice of the spatial weights matrix, a significant direct wage curve elasticity of about 3 per cent in absolute terms is obtained. Noticeable differences occur with regard to the spillover elasticity. While the negative sign is confirmed, unemployment spillovers appear to be significant with a threshold of 60 minutes, but nonsignificant for longer travel times. The autoregressive coefficient of the disturbances is highly significant, except of the shortest-distance spatial weights matrices.

\footnotetext{
${ }^{7}$ For a maximum travel time distance of 60 minutes, two unconnected labour market regions appear (SpreeNeiße and Saale-Orla). In order to enable the estimation of spatial models, in each case the nearest labour market region with travel time distances of 71 and 68 minutes, repectively, is considererd as a neighbour.
} 
Stakhovych and Bijmolt (2008) suggest selecting the correct specification on the basis of log likelihood or information criteria. Because of the same number of variables in all models, the log likelihood statistic is applied. According to this criterium the contiguity approach clearly outperforms the distance approach.

Table 7: Sensitivity of the SpEM-IV on choice of spatial weights matrix

\begin{tabular}{|l|l|l|l|l|l|l|}
\hline & Contiguity & $60 \mathrm{~min}$. & $75 \mathrm{~min}$. & $90 \mathrm{~min}$ & $105 \mathrm{~min}$ & $120 \mathrm{~min}$. \\
\hline$\Delta \mathrm{W}$ & $0.0332^{\star \star}$ & 0.0031 & $0.0229^{\star}$ & $0.0354^{\star \star}$ & $0.0567^{\star \star}$ & $0.0580^{\star \star}$ \\
$\log \left(\mathrm{u}_{\mathrm{t}}\right)$ & $(0.0088)$ & $(0.0093)$ & $(0.0090)$ & $(0.0092)$ & $(0.0132)$ & $(0.0137)$ \\
\hline $\mathrm{EC}_{\mathrm{t}-1}$ & $-0.3425^{\star \star}$ & $-0.2822^{\star \star}$ & $-0.2880^{\star \star}$ & $-0.3005^{\star \star}$ & $-0.3034^{\star \star}$ & $-0.2988^{\star \star}$ \\
& $(0.0442)$ & $(0.0439)$ & $(0.0442)$ & $(0.0441)$ & $(0.0432)$ & $(0.0432)$ \\
\hline $\mathrm{W} \mathrm{EC}_{\mathrm{t}-1}$ & $-0.2202^{\star}$ & 0.0348 & -0.0283 & -0.1297 & -0.1948 & -0.2314 \\
& $(0.0937)$ & $(0.0528)$ & $(0.0720)$ & $(0.1030)$ & $(0.1230)$ & $(0.1596)$ \\
\hline $\mathrm{F}$ & $17.278^{\star \star}$ & $15.778^{\star \star}$ & $16.094^{\star \star}$ & $17.663^{\star \star}$ & $17.220^{\star \star}$ & $16.995^{\star \star}$ \\
\hline
\end{tabular}

Finally, Table 7 reports IV estimation results of the SpEC models with different specifications of the spatial weights matrix. Irrespective of the choice of the spatial weights, local error-correction is effective. For the distance-based weights matrix, the speed of adjustment towards equilibrium tends to be slightly lower than for the contiguity matrix. In al cases, the spatial error-correction mechanism is ineffective. Spatial disparities in equilibrium wages will persist or even increase over time.

\section{Conclusions}

Spatial econometric approaches devoted to the analysis of the wage curve usually ignore the presence of nonstationary variables. In this case, the risk of spurious regression occurs. For East Germany, the CIPS test disclosed non-stationarity of variables in the wage-unemployment nexus that may be captured in a cointegration framework. In order to analyse both local and spatial adjustment processes, a global cointegration approach is adopted. Adjustment to equilibrium along with short-run effects on wages is examined on the basis of a spatial error-correction model.

Spatial econometric analysis reveals distortions in estimating the wage curve with data from administrative areas. The effects relate to both the region's own and spillover unemployment elasticity. While no East German wage curve can be substantiated with data for administrative districts, its existence is clearly proved for functional labour market regions. 
With a view to the theory of monosonistic competition, the long-run relationship between wages and unemployment is analysed in a fixed-effects model that includes the spatialy lagged unemployment rate (FE-SLX model). The relationship is controlled for effects of work experience, qualification, gender, working time, sectoral composition and firm size. A spatial error process is introduced to capture potential influences of other spatilally autocorrelated variables (FE-SLX-SEM model). In order to account for potential endogeneity, the unemployment rate is instrumented.

Applying instrument estimation methods does not substantially affect the estimate of the region's own wage curve elasticity, but the estimate of the spillover elasticity. The highly significant direct uemployment elasticity of 3 per cent corroborates the existence of a wage curve across East German labour markets. While earlier studies report a stronger responsiveness of wages to local labour market conditons, this estimate is well in line with the finding of Elhorst, Blien and Wolf (2007). In instrumenting the unemployment rate, a weak significant spillover elasticity of roughly the same size is inferred. The lower significance reflects the greater variability of spatial externalities. Up to now, there is still a lack of knowledge on the importance of unemployment spillovers in East Germany.

On the basis of a spatial error-correction model it is revealed that wages und the unemployment rate are locally but not globally cointegrated. While the errorcorrection mechanism works within East German labour market regions, it is not effective between the functional areas. In contrast to the West German experience (see Kosfeld and Dreger 2017), a spatial adjustment to equilibrium does not take place across East German regions. A sensitivity analysis shows the robustness of the findings with respect to contiguity- and distance-based spatial weights matrices. Further research should pursue the cointegration approach to investigate the heterogeneity in wage curve effects and the error-correction mechanism with respect to different groups of workers and types of regions.

From a policy point of view, the finding of a local error-correction mechanism in conjunction with increasing disparities in wages across East German regions demands attention. In Germany, a discussion on the appropriate design of a system for promoting less developed regions and areas with particular structural problems from 2020 onwards has evolved. At present the common task "Improvement of regional economic structure" (GRW) mainly ensures the scattergun approach of 
comprehensive supporting East German regions. Policymakers must be aware that untargeted subsidies bear the danger of further increasing regional disparities. As a consequence, regional development policies should not continue to distribute subsidies to East German regions in a non-selective way. Instead, the focus should lie on growth poles and clusters in backward regions (s. a. Kubis, Titzes and Ragnitz 2007).

Actually, some East German regions are even more prosperous than a number of old industrial West German regions. Therefore, the East/West divide of subsidy policy has become overtaken. In view of this development, regional policy should focus promotion to lagging regions and areas with structural problems in both parts of the country. 


\section{References}

Ammermüller, A., Lucifora, C., Origo, F., Zwick, T. (2012), Wage Flexibility in Regional Labour Markets: Evidence from Italy and Germany, Regional Studies 44, 401-421.

Anselin, L. (1988), Spatial Econometrics: Methods and Models, Springer, Dordrecht.

Baltagi, B. H., Baskaya, Y. S., Hulagu, T. (2012), The Turkish wage curve: Evidence from the household labor force survey. Economics Letters 114, 128-131.

Baltagi, B. H., Blien, U. (1998), The German wage curve: Evidence from the IAB employment sample, Economics Letters 61, 135-142.

Baltagi, B.H., Blien, U., Wolf, K. (2009), New evidence on the dynamic wage curve for Western Germany: 1980-2004, Labour Economics 16, 47-51.

Baltagi, B.H., Blien, U., Wolf, K. (2012), A dynamic spatial panel data approach to the German wage curve, Economic Modelling 29, 12-21.

Beenstock, M., Felsenstein, D. (2010), Spatial error correction and cointegration in nonstationary panel data: regional house prices in Israel, Journal of Geographical Systems 12, 189-206.

Beenstock, M., Felsenstein, D. (2015), Estimating spatial spillover in housing construction with nonstationary panel data, Journal of Housing Economics 28, 42-58.

Blanchflower, D. G., Oswald, A. J. (1990), The wage curve, Scandinavian Journal of Economics 92, 215-235.

Blanchflower, D. G., Oswald, A. J. (1994), The wage curve, MIT Press, Cambridge and London.

Blanchflower, D. G., Oswald, A. J. (1995), An Introduction to the Wage Curve, Journal of Economic Perspectives 9, 153-167.

Blanchflower, D. G., Oswald, A. J. (2005), The Wage Curve Reloaded, NBER Working Paper No. 11338

Campbell, C., Orszag, J.M. (1998), A Model of the Wage Curve, Economic Letters 59, 119-125.

Card, D. (1995), The Wage Curve: A Review, Journal of Economic Literature 33, 785-799. 
Elhorst, J. P., Blien, U., Wolf, K. (2007), New evidence on the wage curve: A spatial panel approach. International Regional Science Review 30, 173-191.

Elhorst J.P. (2010), Spatial Panel Data Models, in: Fischer, M.M., Getis A. (eds.), Handbook of Applied Spatial Analysis. Springer, Berlin, Heidelberg, Germany, 377407.

Elhorst, J.P. (2014), Spatial Econometrics - From Cross-Sectional Data to Spatial Panels, Springer, Heidelberg, Germany.

Fingleton, B., Palombi, S. (2013), The Wage Curve Reconsidered: Is it Truly an 'Empirical Law of Economics'?, Région et développement 38, 49-92.

Fitzenberger, B., Kohn, K., Lembcke, A. (2013), Union Density and Varieties of Coverage: The Anatomy of Union Wage Effects in Germany. Industrial and Labor Relations Review 66, 169-197.

García-Mainar, I., Montuenga-Gómez,V.M. (2012), Wage dynamics in Spain: evidence from individual data (1994-2001 Investigaciones Regionales 24, 41-56:

Greene, W.H. (2011), Econometric analysis, 7th ed., Prentice Hall, Upper Saddle River, New Jersey.

Hagen, T. (2003), Three Approaches to the Evaluation of Active Labour Market Policy in East Germany Using Regional Data, Centre for European Economic Research (ZEW), Discussion Paper No. 03-27, Mannheim, Germany.

Harris, J., Todaro, M. (1970), Migration, Unemployment and Development: A TwoSector Analysis, American Economic Review 60, 126-142.

Hilbert, C. (2008), Unemployment, wages, and the impact of active labour market policies in a regional perspective, Logos, Berlin

Im, K.S., Pesaran, M.H., Shin, Y. (2003), Testing for unit roots in heterogeneous panels. Journal of Econometrics 115, 53-74.

Kosfeld, R., Dreger, C. (2017), Local and Spatial Cointegration in the Wage Curve A Spatial Panel Analysis of West German Regions, Review of Regional Research, Online First, 1-23.

Kosfeld, R., Werner, A. (2012), Deutsche Arbeitsmarktregionen - Neuabgrenzung nach den Kreisgebietsreformen 2007-2011, Raumforschung und Raumordnung 70, 49-64. 
Kropp, P., Schwengler, B. (2016), Three-step method for delineating functional labour market regions. Regional Studies 50, 429-445.

Kubis, A., Titze, M., Ragnitz, J (2007), Spillover Effects of Spatial Growth Poles - a Reconciliation of Conflicting Policy Targets?, IWH-Discussion Papers, No. 8/2007, Halle (Saale), Germany.

LeSage, J.P., Pace, R.K. (2009), Introduction to Spatial Econometrics, Chapman \& Hall/CRC, Boca Raton, FL.

LeSage, J.P., Pace, R.K. (2010), Spatial Econometric Models, in: Fischer, M.M., Getis, A. (eds.), Handbook of Applied Spatial Analysis - Software Tools, Methods and Applications, Springer, Berlin, Heidelberg, pp. 355-376.

LeSage, J.P., Pace, R.K. (2014), The biggest myth in spatial econometrics. Econometrics 2, 217-249.

Longhi S., Nijkamp P., Poot J. (2006), Spatial Heterogeneity and the Wage Curve Revisited, Journal of Regional Science 46, 707-731.

Mitze, T., Özyurt, S. (2014), The Spatial Dimension of Trade- and FDI-driven Productivity Growth in Chinese Provinces: A Global Cointegration Approach, Growth and Change 45, 263-291.

Moulton, B.R. (1990), An Illustration of a Pitfall in Estimating the Effects of Aggregate Variables on Micro Units, Review of Economics and Statistics 72, 334-338.

Nijkamp, P., Poot, J. (2005), The Last Word on the Wage Curve? A Meta-Analytic Assessment, Journal of Economic Surveys 19, 421-450.

Pannenberg, M., Schwarze, J. (1998), Labor market slack and the wage curve, Economics Letters 58, 351-354.

Pannenberg, M., Schwarze, J. (2000), 'Phillips Curve' or 'Wage Curve': Is there really a puzzle? Evidence for West Germany, Labour 14, 645-655.

Pesaran, M.H. (2007), A Simple Panel Unit Root Test in the Presence of CrossSection Dependence, Journal of Applied Econometrics 22, 265-312.

Ramos, A., Nicodemo, C., Sanmorá, E. (2014), A spatial panel wage curve for Spain, Letters in Spatial and Resource Sciences 8, 125-139. 
Seifert, H., Massa-Wirth, H. (2005), Pacts for employment and competitiveness in Germany, Industrial Relations Journal 36, 217-240.

Shapiro, C., Stiglitz, J.E. (1984), Equilibrium Unemployment as a Worker Discipline Device, American Economic Review 74, 433-444.

Schnabel, Claus (2016), United, Yet Apart? A Note on Persistent Labour Market Differences Between Western and Eastern Germany, Jahrbücher für Nationalökonomie und Statistik/Journal of Economics and Statistics 236, 157-180.

Stakhovych, S., Bijmolt, T.H.A. (2008), Specification of spatial models: A simulation study on weights matrices, Papers in Regional Science 88, 389-409.

Topel, R.H. (1986), Local labor markets, Journal of Political Economy 94, Supplement, 111-143.

Wagner, J. (1994), German wage curves 1979-1990. Economics Letters 44, 307311.

Wang, Y., Kockelman, K.M., Wang, X.C. (2013), The impact of weight matrices on parameter estimation and inference: $A$ case study of binary response using land-use data, Journal of Transport and Land Use 6, 75-85. 